\title{
Carnitine and carnitine orotate affect the expression of the prolactin-releasing peptide gene
}

\author{
H.S. Zhu, Y.Y. Wang, M.W. Lin, J.X. Du, L.Q. Hang, Y. Chen and \\ L.F. Wang \\ Key Lab of Regulation on Animal Growth and Development of Agricultural \\ Ministry of China, Henan Agricultural University, Zhengzhou, P.R. China \\ Corresponding author: L.F. Wang \\ E-mail: zhuheshui@163.com
}

Genet. Mol. Res. 10 (4): 3013-3019 (2011)

Received December 9, 2010

Accepted March 21, 2011

Published December 6, 2011

DOI http://dx.doi.org/10.4238/2011.December.6.1

\begin{abstract}
Carnitine is involved in fatty acid metabolism in mammals and is widely used as a nutritional supplement; carnitine orotate is a more absorbable form of carnitine. We investigated the effects of carnitine and carnitine orotate on mouse prolactin-releasing peptide (PrRP) mRNA expression. Twenty-four female mice were randomly divided into four groups of six; control mice were orally drenched with physiological saline solution $(250 \mathrm{mg} / \mathrm{kg}$ body weight) and treatment mice were orally drenched with carnitine $(250 \mathrm{mg} / \mathrm{kg})$ or carnitine orotate $(250$ or $750 \mathrm{mg} / \mathrm{kg}$ ), once a day, for 20 days from parturition. The carnitine or carnitine orotate was dissolved in saline solution before administration. The hypothalamus, pituitary and ovary were sampled on day 21 after parturition, and PrRP mRNA levels in these tissues were measured by semi-quantitative PCR, with glyceraldehyde 3-phosphate dehydrogenase as a control. Expression of PrRP in mice treated with carnitine and carnitine orotate was significantly increased in the ovary and significantly reduced in the pituitary gland. Compared with the control, hypothalamus PrRP mRNA increased significantly
\end{abstract}


in the carnitine and low-dose carnitine orotate groups and decreased significantly in the high-dose carnitine orotate group. We conclude that carnitine and carnitine orotate regulate expression of PrRP in the pituitary gland and ovaries.

Key words: Prolactin-releasing peptide; Carnitine; Orotate

\section{INTRODUCTION}

Carnitine is a vital substance in energy metabolism as a carrier to transport long-chain fatty acids from the cytoplasm to the mitochondria, so as to allow $\beta$-oxidation of fatty acids. Nowadays, carnitine is widely used in animal feed as a new non-harmful additive with multiple physiological and biological functions.

Studies showed that piglets of sows fed diets supplemented with L-carnitine grow faster during the suckling period than piglets of control sows fed diets without L-carnitine. Lcarnitine-treated sows had larger litters and higher litter weights than control sows. Also, milk of L-carnitine-treated sows had higher concentrations of total and free carnitine than milk of control sows (Ramanau et al., 2004, 2005; Birkenfeld et al., 2006).

Carnitine orotate is a salt of carnitine and orotate and is better adsorbed compared to carnitine itself. Carnitine and carnitine orotate show extensive prospects as multi-function additives in the feed industry.

Prolactin-releasing peptide (PrRP) is a neuropeptide identified as an endogenous ligand for the orphan $\mathrm{G}$ protein-coupled receptor. This peptide specifically stimulates PRL secretion from pituitary tissue in both in vitro and in vivo assays and does not affect the secretion of other anterior pituitary hormones (Hinuma et al., 1998). To date, detailed studies of PrRP have focused mainly on the rat and the distribution of PrRP in the central nervous system, and little information is available for other species and about the correlation between PrRP and other factors. The present investigation was undertaken to evaluate the impact of carnitine and carnitine orotate drenching on mouse PrRP mRNA expression, in order to determine the correlation between carnitine, carnitine orotate and PrRP.

\section{MATERIAL AND METHODS}

\section{Animals and treatment}

Mice were obtained from the Centre for Laboratory Animals of Henan Province. Animals were maintained in group cages under controlled conditions of temperature $\left(25^{\circ} \pm 1^{\circ} \mathrm{C}\right)$ and in a 12/12-h light/dark cycle, with ad libitum access to food and water. The stage of the estrous cycle was monitored by collection of daily vaginal smears, and those showing at least 2 consecutive estrous cycles were used. Groups of proestrus mice were paired with males at a 2:1 ratio, and matings were confirmed by the presence of sperm in the vaginal smear the following day. Pregnant animals were monitored daily to define the day of lactation. Twentyfour female mice were divided into four groups $(\mathrm{N}=6)$. Treatment animals were drenched with carnitine or carnitine orotate for 20 days from parturition, at $6 \mathrm{pm}$, and control mice were drenched with saline (Table 1). Groups of mice $(\mathrm{N}=6)$ on day 21 of lactation were killed at 
9 am by decapitation. The hypothalamus, pituitary and ovary were rapidly removed and immediately frozen with liquid nitrogen.

Table 1. Supplement administration for animals.
\begin{tabular}{lcll}
\hline Group & Animals & Supplement & Dose \\
\hline A & 6 & Carnitine & $250 \mathrm{mg} / \mathrm{kg}$ body weight \\
B & 6 & Carnitine orotate & $750 \mathrm{mg} / \mathrm{kg}$ body weight \\
C & 6 & Carnitine orotate & $250 \mathrm{mg} / \mathrm{kg}$ body weight \\
D & 6 & Saline & $250 \mathrm{mg} / \mathrm{kg}$ body weight \\
\hline
\end{tabular}

\section{RNA extraction and reverse transcription}

Total RNA was extracted in the presence of RNA-out and stored at $-80^{\circ} \mathrm{C}$. The concentration of RNA was estimated by spectrophotometry using UV absorbance at 260 and $280 \mathrm{~nm}$. The integrity of RNA was determined by denaturing agarose gel electrophoresis. Total RNA was extracted following a conventional protocol and was dissolved in $20 \mu \mathrm{L}$ RNase-free water.

The RNA was reverse-transcribed with a reaction mix containing $6.5 \mu \mathrm{L}$ DEPC- $\mathrm{H}_{2} \mathrm{O}, 4 \mu \mathrm{L}$ $5 \mathrm{X}$ buffer, $4 \mu \mathrm{L} 2.5 \mathrm{mM}$ dNTP mix, $1 \mu \mathrm{L} 50 \mathrm{pM}$ Oligo (dT) $18,2 \mu \mathrm{L} 5 \mathrm{U} / \mu \mathrm{L}$ AMV, $0.5 \mu \mathrm{L} 40 \mathrm{U} /$ $\mu \mathrm{L}$ RNase inhibitor, $2 \mu \mathrm{L}$ RNA. The total reaction volume was $20 \mu \mathrm{L}$. After gentle mixing, the solution was incubated for $60 \mathrm{~min}$ at $42^{\circ} \mathrm{C}$, and then for $15 \mathrm{~min}$ at $72^{\circ} \mathrm{C}$, followed by chilling in an iced bath for $2 \mathrm{~min}$. Two controls were prepared in the RT reaction mixture: one control was prepared using all reagents except the RNA sample, for which an equivalent volume of water was substituted, and the other control was prepared using all reagents except reverse transcriptase. The controls underwent identical PCR procedures as the experimental samples.

\section{RT-PCR analysis}

Expressions of PrRP mRNA in these tissues were measured by semi-quantitative PCR with GAPDH as control. The cDNAs obtained were further amplified by PCR in total volume mix of $25 \mu \mathrm{L}$, which consisted of $1 \mu \mathrm{L}$ RT reaction solution, $12.5 \mu \mathrm{L} 2 \mathrm{X}$ Master mix, $1 \mu \mathrm{L} 20 \mathrm{pM}$ forward primer, $1 \mu \mathrm{L} 20 \mathrm{pM}$ reverse primer, and $9.5 \mu \mathrm{L}$ sterilized $\mathrm{H}_{2} \mathrm{O}$. The reaction substrates were mixed by gently flicking the bottom of each tube. PCR amplification was carried out for 30 cycles $\left(94^{\circ} \mathrm{C}, 20 \mathrm{~s} ; 62^{\circ} \mathrm{C}, 20 \mathrm{~s} ; 72^{\circ} \mathrm{C}, 20 \mathrm{~s}\right)$ for PrRP and 30 cycles $\left(94^{\circ} \mathrm{C}, 20 \mathrm{~s} ; 57^{\circ} \mathrm{C}, 20 \mathrm{~s} ; 72^{\circ} \mathrm{C}, 20 \mathrm{~s}\right)$ for GAPDH. Samples were finished with the final extension at $72^{\circ} \mathrm{C}$ for $5 \mathrm{~min}$. Every $5-\mu \mathrm{L}$ sample of PCR amplification product was gently mixed with $3 \mu \mathrm{L}$ fluorochrome before protection from light for $10 \mathrm{~min}$, and was then visualized on a 1.5\% agarose gel with a Multi-Image light cabinet. The primers were for GAPDH: forward 5'-ACCACAGTCCATGCCATCAC-3', reverse 5'-TCCACCACCCTGTTGCTGTA-3', and for PrRP: forward 5'-GACGTGGCTTCTGTGCTTGCTGCTG-3', reverse 5'-GCAGCACTGTCT TCTCGAGCTG-3'. The predicted sizes of PCR products of GAPDH and PrRP were 452 and $262 \mathrm{bp}$, respectively.

\section{Statistical treatment of results}

All results are reported as means \pm SD and were analyzed by the Statistical Package 
for the Social Sciences (SPSS) statistical software (version 13.0). Differences among group data were compared using the Student-Newman-Keuls post hoc test of one-way analysis of variance (ANOVA), and differences between groups were compared using the paired-sample $t$-test. Significance was set at $\mathrm{P}<0.05$ and $\mathrm{P}<0.01$ in two-tailed testing.

\section{RESULTS}

Gel electrophoresis showing RT-PCR of PrRP in the hypothalamus-pituitary-ovary axis (HPOA) indicated that a single-PCR product of about 262 bp was obtained in all samples (Figure 1).

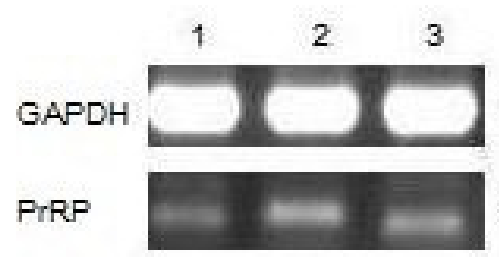

A

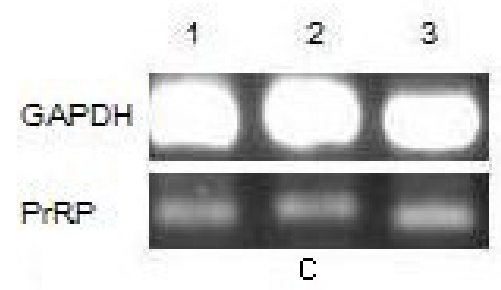

$452 \mathrm{bp}$



452 bp

$262 \mathrm{bp}$

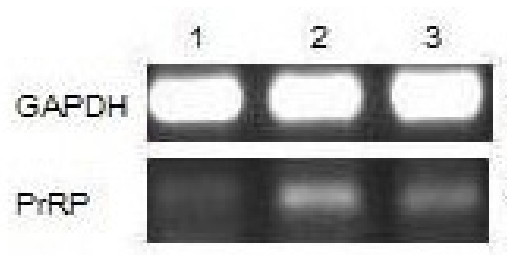

$452 \mathrm{bp}$

$262 \mathrm{bp}$

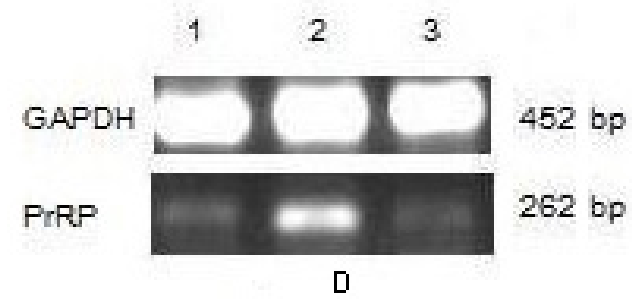

Figure 1. Gel electrophoresis of RT-PCR products for prolactin-releasing peptide (PrRP) and GAPDH in hypothalamus-pituitary-ovary axis after supplement administration. $\mathbf{A}, \mathbf{B}, \mathbf{C}$, and $\mathbf{D}$ represent the four study groups; lane 1 = hypothalamus; lane 2 = pituitary; lane 3 = ovary.

The relative expression levels of PrRP mRNA in HPOA after supplement administration are shown in Figure 2. Compared with saline administration (0.14), PrRP mRNA levels in the hypothalamus after carnitine drenching $(0.25)$ and low dose carnitine orotate $(0.29)$ were significantly increased $(\mathrm{P}<0.05)$; however, PrRP mRNA after drenching with high dose carnitine orotate decreased notably $(\mathrm{P}<0.05)$.

Compared with saline administration (0.70), PrRP mRNA levels in the pituitary after carnitine drenching, low-dose carnitine orotate and high-dose carnitine orotate were significantly decreased to values of $0.28,0.37$ and 0.29 , respectively $(\mathrm{P}<0.05)$, but there was no significant difference between the latter three supplement groups $(\mathrm{P}>0.05)$.

Compared with saline administration (0.06), PrRP mRNA in the pituitary after carnitine drenching, low-dose carnitine orotate and high-dose carnitine orotate were significantly increased with values of $0.30,0.35$ and 0.21 , respectively $(\mathrm{P}<0.05)$. At the same time, $\operatorname{PrRP}$ mRNA levels in the pituitary after carnitine drenching and low-dose carnitine orotate were significantly higher compared with that of high dose carnitine orotate $(\mathrm{P}<0.05)$. 


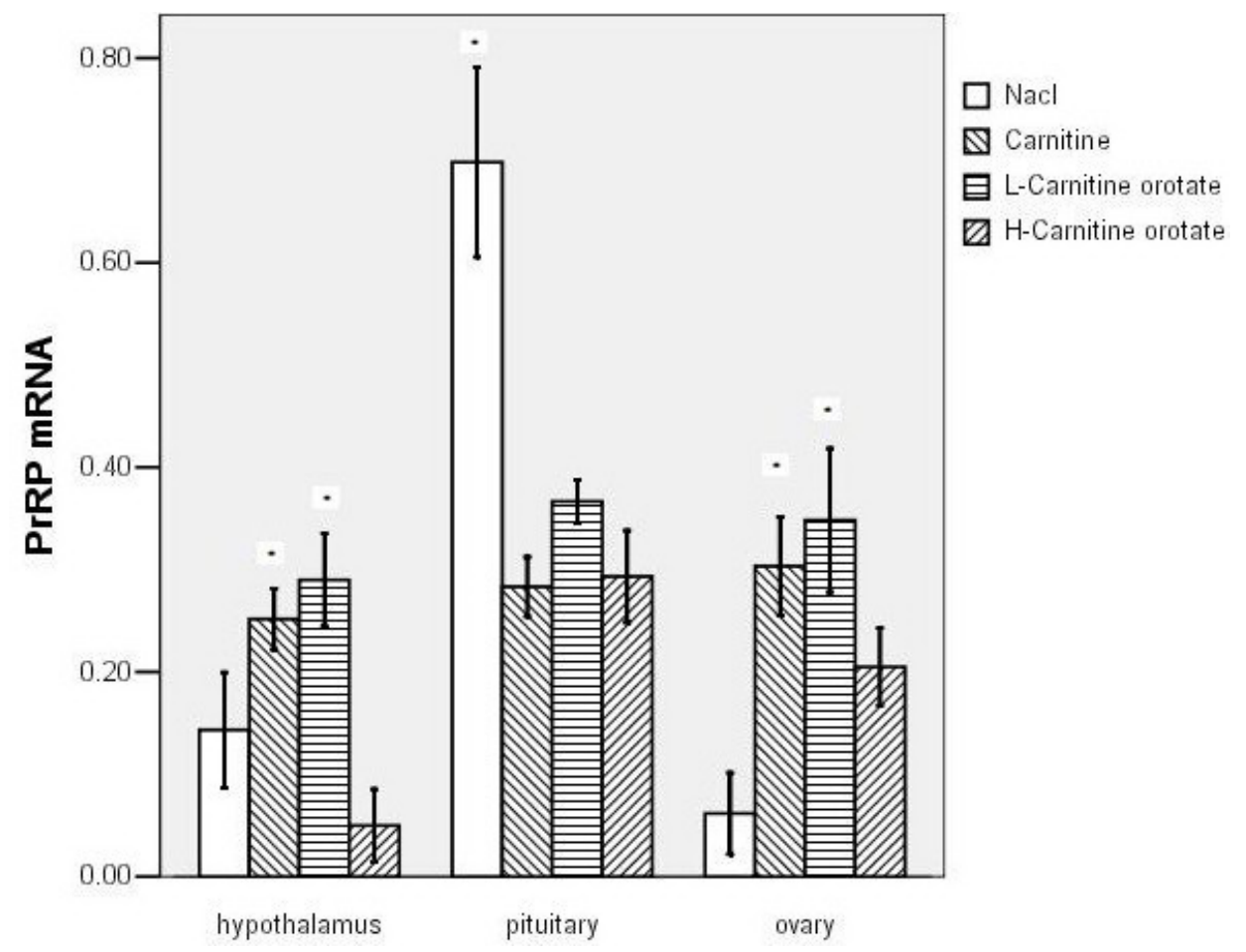

Figure 2. Change in prolactin-releasing peptide (PrRP) mRNA in hypothalamus-pituitary-ovary axis after supplement administration. $* \mathrm{P}<0.05$.

\section{DISCUSSION}

During the developmental stages of rat fetuses and neonates, PrRP mRNA in the hypothalamus is first expressed at postnatal day 13 (P13) (Yano et al., 2001). From embryonic day 14 to postnatal day 0, during the embryonic expression, PrRP genes show weak but even in situ hybridization signals in the pituitary (Nieminen et al., 2003). At different stages of the estrous cycle, the highest level of PrRP expression in the hypothalamus is located in the dorsomedial aspect of the ventromedial hypothalamus. All other hypothalamic regions exhibit significantly $(\mathrm{P}<0.05)$ lower levels of expression, including the rostral and caudal dorsomedial hypothalamus. Very low levels of PrRP expression have been observed in the arcuate nucleus, paraventricular nucleus, medial preoptic nucleus, and ventrolateral aspect of the ventromedial hypothalamus. No significant changes in PrRP expression were noted in the hypothalamus between proestrus, estrus or diestrus (Anderson et al., 2003). However, other research showed that PrRP immunoreactive (ir) neurons in the ventrolateral reticular nucleus (VLRN) in proestrus were less than those in the diestrus, estrus and metaestrus. Similarly, the relative optical density of ir-PrRP fibers of the bed nucleus of stria terminalis (BST) in proestrus was decreased compared with those in the three other groups (Feng et al., 2007).

As far as the factors influencing PrRP are concerned, electroacupuncture (EA) (Yao et al., 2007) and sodium tanshinone IIA sulfonate (STS) (Xiao et al., 2006) significantly increase the blood 
level of $\mathrm{E}_{2}$ and the expression of PrRP in the medulla oblongata of ovariectomized (OVX) rats. The number of PrRP immunoreactive neurons was higher in the OVX group submitted to EA than that in the control OVX group. The mechanism underlying the ability of EA and STS to improve conditions in reproductive disorders induced by ovariectomy in rats is related to the modulation of blood $\mathrm{E}_{2}$ levels and the expression of PrRP in the medulla oblongata (Xiao et al., 2006; Yao et al., 2007).

Acute administration of nicotine could activate PrRP-bearing neurons in the A2 area of the nucleus tractus solitarius (NTS) of rats. When rats were treated chronically with nicotine, the results showed that the body weight was strongly reduced and food intake was greatly suppressed compared to the vehicle control group. Further immunocytochemical studies revealed that PrRP-bearing neurons in the NTS were evidently activated after chronic administration of nicotine, suggesting that PrRP was involved in the regulation of nicotine-mediated body weight loss and food intake suppression in rats.

At the same time, nicotine/stress and saline/stress both activated the majority of the PrRP neurons in the NTS. This indicated that PrRP was associated with stress responses, but it had little effect on nicotine-mediated stress responses. PrRP is involved in the nicotineinduced regulation of body weight and food intake, but may not be involved in nicotinemediated stress responses (Sun et al., 2005).

In the hypothalamus and brainstem of streptozotocin-induced diabetic rats, PrRP mRNA levels were significantly reduced in comparison with those of control rats. After insulin-treatment, PrRP mRNA levels in fa/fa diabetic rats were significantly increased. The diabetic condition and insulin treatment may affect the regulation of PrRP gene expression via leptin and other factors, such as plasma glucose level (Mera et al., 2007).

Medullary PrRP neurons are negatively regulated by changes in lactation (presumably hormonal), and are not recruited to activation by suckling stimuli. PrRP mRNA signal was reduced in the medulla of lactating dams, relative to both male and diestrus female controls, with cell counts revealing 42 and $43 \%$ reductions in the number of positively labeled cells in the NTS and ventrolateral medulla, respectively. By contrast, acute exposure to hypotensive hemorrhage or footshock each activated substantial complements of medullary neurons expressing PrRP mRNA. A substantially greater fraction of the total medullary PrRP population exhibited sensitivity to footshock compared to hemorrhage (Morales and Sawchenko, 2003).

In this study, the results showed that ovary PrRP levels of treatment mice were higher than in control mice, and that treatment with L-carnitine and low-dose L-carnitine orotate could significantly enhance hypothalamus PrRP levels. This indicated that effects of L-carnitine orotate on PrRP expression may differ depending on dose. The mechanism underlying L-carnitine influence is not known, and L-carnitine may modulate PrRP mRNA by eliciting stress or by an action on the hypothalamus-pituitary-ovary axis.

\title{
ACKNOWLEDGMENTS
}

\author{
Research supported by the National Key Basic Research Program of China \\ (\#2011CB100800).
}

\section{REFERENCES} Anderson ST, Kokay IC, Lang T, Grattan DR, et al. (2003). Quantification of prolactin-releasing peptide (PrRP) mRNA
expression in specific brain regions of the rat during the oestrous cycle and in lactation. Brain Res. 973: 64-73. 
Birkenfeld C, Kluge H and Eder K (2006). L-carnitine supplementation of sows during pregnancy improves the suckling behaviour of their offspring. Br. J. Nutr. 96: 334-342.

Feng Y, Zhao H, An XF, Ma SL, et al. (2007). Expression of brain prolactin releasing peptide (PrRP) changes in the estrous cycle of female rats. Neurosci. Lett. 419: 38-42.

Hinuma S, Habata Y, Fujii R, Kawamata Y, et al. (1998). A prolactin-releasing peptide in the brain. Nature 393: 272-276.

Mera T, Fujihara H, Saito J, Kawasaki M, et al. (2007). Downregulation of prolactin-releasing peptide gene expression in the hypothalamus and brainstem of diabetic rats. Peptides 28: 1596-1604.

Morales T and Sawchenko PE (2003). Brainstem prolactin-releasing peptide neurons are sensitive to stress and lactation. Neuroscience 121: 771-778.

Nieminen ML, Nystedt J and Panula P (2003). Expression of neuropeptide FF, prolactin-releasing peptide, and the receptor UHR1/GPR10 genes during embryogenesis in the rat. Dev. Dyn. 226: 561-569.

Ramanau A, Kluge H, Spilke J and Eder K (2004). Supplementation of sows with L-carnitine during pregnancy and lactation improves growth of the piglets during the suckling period through increased milk production. J. Nutr. 134: 86-92.

Ramanau A, Kluge H and Eder K (2005). Effects of L-carnitine supplementation on milk production, litter gains and backfat thickness in sows with a low energy and protein intake during lactation. Br. J. Nutr. 93: 717-721.

Sun B, Nemoto H, Fujiwara K, Adachi S, et al. (2005). Nicotine stimulates prolactin-releasing peptide (PrRP) cells and non-PrRP cells in the solitary nucleus. Regul. Pept. 126: 91-96.

Xiao Y, Qing WX, Lan MS and Ying CB (2006). Sodium tanshinone IIA sulfonate derived from Slavia miltiorrhiza Bunge up-regulate the expression of prolactin releasing peptide (PrRP) in the medulla oblongata in ovariectomized rats. Biochem. Pharmacol. 72: 582-587.

Yano T, Iijima N, Kataoka Y, Hinuma S, et al. (2001). Developmental expression of prolactin releasing peptide in the rat brain: localization of messenger ribonucleic acid and immunoreactive neurons. Brain. Res. Dev. Brain. Res. 128: 101-111.

Yao X, Wang XQ, Ma SL and Chen BY (2007). Electroacupuncture stimulates the expression of prolactin-releasing peptide (PrRP) in the medulla oblongata of ovariectomized rats. Neurosci. Lett. 411: 243-248. 